\title{
CORRIGENDUM
}

\section{Autism spectrum disorders and autistic traits share genetics and biology}

J Bralten, KJ van Hulzen, MB Martens, TE Galesloot, A Arias Vasquez, LA Kiemeney, JK Buitelaar, JW Muntjewerff, B Franke and G Poelmans

Molecular Psychiatry advance online publication, 20 June 2017; doi:10.1038/mp.2017.127

Correction to: Molecular Psychiatry advance online publication, 16 May 2017; doi: 10.1038/mp.2017.98

The following information was omitted from the Acknowledgements :

This study was further supported by the Innovative Medicines Initiative (IMI) Joint Undertaking under grant agreement no. 115300 (EU-AIMS), resources of which are composed of financial contribution from the European Community's Seventh Framework Program (FP7/2007-2013) and the European Federation of Pharmaceutical Industries and Associations (EFPIA) companies' in kind contribution. (c) (i) $\Theta$ This work is licensed under a Creative Commons AttributionNonCommercial-NoDerivs 4.0 International License. The images or other third party material in this article are included in the article's Creative Commons license, unless indicated otherwise in the credit line; if the material is not included under the Creative Commons license, users will need to obtain permission from the license holder to reproduce the material. To view a copy of this license, visit http:// creativecommons.org/licenses/by-nc-nd/4.0/

C The Author(s) 2017 